\title{
Comparison between Curing Conditions of Zeolite and Siltstone Cement Pastes at Low W/B Ratio after 91 Days
}

\author{
Mauricio H. Cornejo, $\mathrm{PhD}^{1}$, Jan Elsen, $\mathrm{PhD}^{2}$, and Haci Baykara, $\mathrm{PhD}^{1}$, Cecilia Paredes, $\mathrm{PhD}^{1}$, Andres Rigail, D. Eng ${ }^{1}$ \\ ${ }^{1}$ Escuela Superior Politécnica del Litoral, ESPOL, Facultad de Ingeniería Mecánica y Ciencias de la Producción, \\ Campus Gustavo Galindo Km 30.5 Vía Perimetral, P.O. Box 09-01-5863, Guayaquil, Ecuador, \\ mcornejo@espol.edu.ec, hbaykara@espol.edu.ec, cparedes@espol.edu.ec, arigail@espol.edu.ec \\ ${ }^{2}$ Department of Earth and Environmental Science, Faculty of Science, Katholieke Universiteit Leuven, Leuven, \\ Belgium, jan.elsen@ees.kuleuven.be
}

\begin{abstract}
This study deals with a comparison between water and air cured blended cement pastes at a Water-to-binder (W/B) ratio of 0.3 after ageing for 91 days. Supplementary Cementitious Materials (SCMs) like zeolitic tuffs are widely used to improve compressive strength by the pozzolanic reaction. In this study, mordenite rich tuff, a mixture of clinoptilolite-heulandite-mordenite-calcite, and calcareous siltstone were blended with Ordinary Portland cement (OPC) at levels ranged from 5 to $27.5 \%$. Using quantitative $X$-ray diffraction (QXRD), Thermal gravimetric analysis - Differential scanning calorimetry (TGA-DSC), as well as density measurements and compressive strength, some hydration parameters such as content of calcium hydroxide (CH), anhydrous cement phases, calcite, and water in hydrates, density and the mechanical performance were determined. The results showed that hydration process of blended cement pastes was uncomplete at ages as late as 91 days regardless of curing conditions. The air cured cement pastes showed a less content of $\mathrm{CH}$, water in hydrates, and compressive strength, but instead a higher density and content of carbonate-like minerals with respect to their water-cured counterparts. The pozzolanic reaction scarcely proceeded at a W/B ratio of 0.3 regardless of curing condition. Among the SCMs, mordenite rich tuff blended cement pastes presented the best compressive strength values, when was cured under water; the others showed better values of compressive strength in air curing condition.
\end{abstract}

Keywords-Zeolitic tuffs, Hydration process, blended cement pastes, pozzolanic reaction.

Digital Object Identifier (DOI):http://dx.doi.org/10.18687/LACCEI2016.1.1.165

ISBN: 978-0-9822896-9-3

ISSN: $2414-6390$

$14^{\text {th }}$ LACCEI International Multi-Conference for Engineering, Education, and Technology: "Engineering Innovations for Global Sustainability", 20-22 July 2016, San José, Costa Rica. 


\title{
Comparison between Curing Conditions of Zeolite and Siltstone Cement Pastes at Low W/B Ratio after 91 Days
}

\author{
Mauricio H. Cornejo, $\mathrm{PhD}^{1}$, Jan Elsen, $\mathrm{PhD}^{2}$, and Haci Baykara, $\mathrm{PhD}^{1}$, Cecilia Paredes, $\mathrm{PhD}^{1}$, Andres Rigail, D. Eng ${ }^{1}$ \\ ${ }^{1}$ Escuela Superior Politécnica del Litoral. ESPOL, Facultad de Ingeniería Mecánica y Ciencias de la Producción, Campus Gustavo \\ Galindo Km 30.5 Vía Perimetral, P.O. Box 09-01-5863, Guayaquil, Ecuador, mcornejo@espol.edu.ec, hbaykara@espol.edu.ec, \\ cparedes@espol.edu.ec, arigail@espol.edu.ec \\ ${ }^{2}$ Department of Earth and Environmental Science, Faculty of Science, Katholieke Universiteit Leuven, \\ Leuven, Belgium, jan.elsen@ees.kuleuven.be
}

\begin{abstract}
This study deals with a comparison between water and air cured blended cement pastes at a Water-to-binder (W/B) ratio of 0.3 after ageing for 91 days. Supplementary Cementitious Materials (SCMs) like zeolitic tuffs are widely used to improve compressive strength by the pozzolanic reaction. In this study, mordenite rich tuff, a mixture of clinoptilolite-heulandite-mordenitecalcite, and calcareous siltstone were blended with Ordinary Portland cement (OPC) at levels ranged from 5 to $27.5 \%$. Using quantitative $X$-ray diffraction (QXRD), Thermal gravimetric analysis - Differential scanning calorimetry (TGA-DSC), as well as density measurements and compressive strength, some hydration parameters such as content of calcium hydroxide $(\mathrm{CH})$, anhydrous cement phases, calcite, and water in hydrates, density and the mechanical performance were determined. The results showed that hydration process of blended cement pastes was uncomplete at ages as late as 91 days regardless of curing conditions. The air cured cement pastes showed a less content of $\mathrm{CH}$, water in hydrates, and compressive strength, but instead a higher density and content of carbonate-like minerals with respect to their water-cured counterparts. The pozzolanic reaction scarcely proceeded at a $W / B$ ratio of 0.3 regardless of curing condition. Among the SCMs, mordenite rich tuff blended cement pastes presented the best compressive strength values, when was cured under water; the others showed better values of compressive strength in air curing condition.

Keywords-Zeolitic tuffs, Hydration process, blended cement pastes, pozzolanic reaction.
\end{abstract}

\section{INTRODUCTION}

Recently, the study of supplementary cementitious materials (SCM) has risen the interest of the scientific community because of environmental, social and technical concerns. The performance of modern cement-based materials must overcome these concerns. Although many studies have been done on SCMs used in cement for almost 80 years, the complete hydration process of blended cement pastes is not yet clearly understood.

The concern about low W/B ratio, curing conditions and hydration products has possibly started since the work of Power and Brownyard in 1947 and recently revised [1], [2]. With respect to engineering properties of cement-based materials, the use of high performance concrete has recently risen because of its application on modern civil infrastructure; this implies the use of a low water-to-binder ratio (W/B) that presents some shortcomings to overcome. Among others, the self-dessication, the self-neutralization, and the slow hydration rate were reported as the main problems over the life time of such structures [3]. An important question remains what the overall effect of SCM on the hydration process and the final assemblages is at such low W/B ratios.

Natural zeolites are brought to attention of scholar due to their availability all over the world, and their usage as dimension stones, lightweight aggregate, and of course, SCM [4]. Colella et al summarized these uses reporting a number of places from Europe to America along of modern history, where zeolites were generally found [5]. In case of zeolites as SCM, Feng and Peng have reported that zeolites in China are not only used as mineral additions in cement-based materials, but also as anti-bacteria agent, expansion inhibitor for alkali-aggregate reaction, non-alkali antifreeze agent, accelerating admixture, addition for cellular concrete, humidity-conditioning material [6].

Comparing to other pozzolans, Poon et al. stated that clinoptilolite (CLI) in terms of the pozzolanic reactivity is between fly ash and silica fume [7]. Luke, on the other hand, pointed out that mordenite (MOR) showed a higher degree of hydration comparing to chabasite, although he also reported that MOR retarded the hydration, while chabasite accelerated it [8]. In another study, Fragoulis et al., using zeolites as SCM, highlighted that despite their almost similar chemical composition, mordenite performed better regarding compressive strength than heulandite under similar experimental conditions and concluded that purity and reactive silica affected the long-term mechanical performance [9]. Scrivener and Nonat have, more recently, concluded that the zeolites react faster than fly ash and some slags despite the fact that zeolites are more crystalline [10].

One of the most remarkable advantages of the use of the zeolites as SCM is for improving the durability of cement-based materials [11]. Rodriguez Camacho and Uribe-Afif stated that zeolites were found more reactive during hydration, and showed a high sulfate resistance [12]; Ahmadi and Shekarchi also reported about the advantage of using zeolites in terms of durability additionally pointing out that $15 \%$ was optimal for replacement [13].

The hardening evolution of blended cement pastes depends mainly on curing conditions. Ramezanianpour, studying the effect of curing conditions on pozzolanic cement, reported that in poor curing conditions, the pozzolana blended cement pastes are more affected than ordinary Portland cement (OPC) pastes [14]. Even, this detrimental effect increased as pozzolana addition increased. Moreover poor curing conditions affect the

Digital Object Identifier (DOI): http://dx.doi.org/10.18687/LACCEI2016.1.1.165 ISBN: 978-0-9822896-9-3 ISSN: $2414-6390$

$14^{\text {th }}$ LACCEI International Multi-Conference for Engineering, Education, and Technology: "Engineering Innovations for Global Sustainability", 20-22 July 2016, San José, Costa Rica. 
early hydration less than long term one. As the pozzolanic activity is a long-term reaction, it will be more affected by the lack of water at early ages. In this sense, Hill and Sharp, using a high replacement in pozzolanic cement cured in dry condition, reported that initially calcium hydroxide $(\mathrm{CH})$ is produced by cement hydration at early ages; but later, it disappeared, although carbonate minerals started to be a meaningful phase because of the carbonation [15]. Therefore, it is expected that the lack of water also affect the hydration of anhydrous cement particles and induce the carbonation.

The use of high water-demanding minerals like natural zeolite increases the above-mentioned shortcomings, although an adequate use of mineral additions can somehow tackle this problem. Therefore, this study is devoted to increase our knowledge on zeolites-cement-water systems, under different curing conditions, expecting that the use of natural zeolite can somewhat be optimized in cement based materials. In other words, the study of the hydration process and compressive strength of blended cement pastes at 91 days after curing in different conditions can be a meaningful step to higher engineering and ecology cement-based materials. In addition, this study compared the use of two zeolitic tuffs and siltstone at different level of dosage indicating if it is possible the use of one of these SCMs as mineral addition in composite cement.

\section{MATERIAL AND METHODS}

In order to determine the difference in terms of hydration parameters and compressive strength between blended cement pastes cured in two different conditions, Ordinary Portland cement blended with two zeolitic tuffs (coded as Zeo1, Zeo2) and one siltstone (coded as Limo) were characterized through the uniaxial compressive strength (UCS), quantitative X-ray diffraction (QXRD), thermogravimetry-differential scanning calorimetry (TGA-DSC) and density. The tests were conducted at 91 days.

The W/B ratio of 0.3 was chosen for this study. This ratio remained constant during the study and was selected because there is a general trend in civil engineering of using high or ultra high performance cement-based material. Any chemical addition was used in this study.

The two curing conditions were water and air. In this study, water curing condition implied that specimens were cured under water at $23 \pm 2^{\circ} \mathrm{C}$; air one was cured under controlled environmental condition inside lab at $25.6 \pm 1.6^{\circ} \mathrm{C}$ and $68.6 \pm$ $3.9 \%$ relative humidity.

\section{A. Materials}

Two zeolitic tuffs and one siltstone were used as SCMs and blended with Ordinary Portland Cement Type I to form blended cement pastes at a W/B ratio of 0.3 cured under two different curing conditions. The two tuffs were different in mineralogy, but similar in chemical composition. One of them is a mordenite-rich tuffs coded as Zeo1 (MOR 70 wt. \%, quartz
(Qz) 17wt. \%), which is located near Guayaquil-Ecuador. The other is a mixture of clinoptilolite-heulandite as well as mordenite, quartz and calcite (CLI-HEU $\sim 23 \mathrm{wt} . \%$, MOR $\sim 45$ wt. $\%$, Qz $\sim 11$ wt. $\%$, Cc $\sim 14$ wt. $\%$ ) and is located $150 \mathrm{~km}$ west of Guayaquil on Pacific sea line. Finally the siltstone coded as Limo that contained quartz, calcite and clayey minerals (CLIHEU $\sim 8$ wt. $\%$, Qz $\sim 47$ wt. \%, Clays $\sim 15$ wt. \%) is also located near Guayaquil.

The physical and chemical characteristic of OPC meets the requirements of Ecuadorian standards (i.e. NTE-INEN 152). In Table I, the technical requirements request for Ecuadorian standard are also presented for comparison. As can be seen, all physical and chemical characteristics of OPC meet the requirements of Ecuadorian standard. LOI and IR also met the requirements of UNE-EN-196-2. Likewise $\mathrm{MgO}$ and $\mathrm{SO}_{3}$ showed values below their maximum contents. However, the fineness shows slight higher values than that reported by scientific literature [16].

TABLE I

PHYSICAL AND CHEMICAL CHARACTERISTICS OF THE USED CEMENT AND THE REQUIREMENT OF THE ECUADORIAN STANDARD FOR COMPARISON

\begin{tabular}{|c|c|c|}
\hline Characteristic & INEN 152 & $\mathrm{OPC}^{*}$ \\
\hline \multicolumn{3}{|c|}{ Chemical } \\
\hline LOI $\max \% * *$ & 3 & 0.8 \\
\hline $\mathrm{MgO} \%$ & 6 & 1.0 \\
\hline $\mathrm{SO}_{3} \%$ & 3.5 & 2.8 \\
\hline IR $\max \% * * *$ & 0.75 & 0.4 \\
\hline \multicolumn{3}{|c|}{ Physical } \\
\hline Autoclave expansion max \% & 0.8 & 0.012 \\
\hline Setting time initial no less than, $\min$ & 45 & 149 \\
\hline Final no more than, min & 375 & 259 \\
\hline Air content, $\max \%$ & 12 & 3.5 \\
\hline \multicolumn{3}{|l|}{ Compressive strength, MPa } \\
\hline 1 days & & 15.2 \\
\hline 3 days & 12 & 26.9 \\
\hline 7 days & 19 & 36.4 \\
\hline 28 days & 28 & 46.1 \\
\hline Equivalent alkalis $\max \%$ & 0.6 & 0.4 \\
\hline False set Penetration $\min \%$ & 50 & 75.0 \\
\hline Blaine, $\min \mathrm{m}^{2} / \mathrm{kg}$ & 260 & 295 \\
\hline
\end{tabular}

\section{B. Experimental procedure}

The samples were picked up from their outcrops. After removing the organic matter, the samples were crushed and milled to reduce the grain size up to passing $70 \%$ by weight throughout sieve $\mathrm{N}^{\circ} 325$ mesh.

The proportioning was the same for both curing conditions. Each level of replacement was chosen by adding $2.5 \%$ starting at $5 \%$ and finishing at $27.5 \%$, apart for control that is $0 \%$ of SCM as can be seen in Table II. After OPC and SCM were blended with tap water, the specimens were cured during 91 days under the two curing conditions. In case of air curing condition, it implies that immediately after demolding at 1 day, the specimens were placed at room conditions inside the laboratory. In case of water curing condition, it implies that

$14^{\text {th }}$ LACCEI International Multi-Conference for Engineering, Education, and Technology: "Engineering Innovations for Global Sustainability”, 20-22 July 2016, San José, Costa Rica. 
specimens were soaked under water at room temperature up to the testing age.

TABLE II

MIX DESIGN FOR BLENDED CEMENT PASTES USED IN EITHER WATER OR AIR CURING CONDITION. THESE AMOUNTS OF SCM AND CEMENT WERE USED TO PREPARE A BATCH OF 12 CUBES OF $50 X 50 X 50 \mathrm{~mm}^{3}$. AS W/B RATIO WAS 0.3, THE CONTEN OF WATER WAS $900 \mathrm{~g}$

\begin{tabular}{|l|l|l|}
\hline Proportioning $(\%)$ & SCM $(\mathrm{g})$ & Cement $(\mathrm{g})$ \\
\hline 0 & & 3000 \\
\hline 5 & 150 & 2850 \\
\hline 7.5 & 225 & 2775 \\
\hline 10 & 300 & 2600 \\
\hline 12.5 & 375 & 2625 \\
\hline 15 & 450 & 2550 \\
\hline 17.5 & 525 & 2475 \\
\hline 20 & 600 & 2400 \\
\hline 22.5 & 675 & 2375 \\
\hline 25 & 750 & 2250 \\
\hline 27.5 & 825 & 2175 \\
\hline
\end{tabular}

1) Compressive strength: ASTM C109 was used as standard for testing the compressive strength at 91 day. An universal testing machine Shimadzu 600KN was used applying a load with accuracy of $0.5 \%$.

Once the universal testing machine broke the specimens at 91 days, some small broken pieces were chosen to be stored under ethanol in a hermetically closed bottle so as to stop the hydration for other tests.

2) Quantitative $x$-ray diffraction (QXRD): PANanalytical ${ }^{\circ} \quad \mathrm{X}^{\prime}$ pert $\mathrm{XRD}$ with $\mathrm{K} \alpha \mathrm{Cu}$ anode tube was used. The operating conditions were $40 \mathrm{~mA}$ and $45 \mathrm{KV}$, step size $0,02^{\circ}$. In addition, High Score Plus ${ }^{\circledR}$ software was used for quantification the crystalline phases and amorphous content. The procedure can be found elsewhere [17]-[19]. The cluster analyses of $\mathrm{x}$-ray diffractograms applied the methodology proposed by Kaufman and Rousseeuw [20]. This methodology is based on multivariate statistical method for assessing clusters of similarity, and even calculated an optimal number of these clusters. In this study, cluster analysis consisted in four-step process:

- Comparison: All scans in experimental setting are compared to each other using position-based figureof-merit, which uses their matching positions to calculate the overall score. The default threshold value is $75 \%$.

- Agglomerative hierarchical cluster analysis: The scans are placed in different cluster according to their similarities calculated by the Manhattan distance.

- Cluster number: it is estimated by KGS test [21]. Kelley et al. proposed to estimate the "right" number of cluster based on the distance measure between scans.

- Principal component analysis: The correlation matrix from comparison is used as input data and the resulting eigenvalues are used as mathematical tool to find systematic variance in data. As a result, 3-eigenvalue plot is displayed to place each data set. The color of the sphere represents the cluster they belong.

3) Thermogravimetry-differential calorimetry (TGA$D S C)$ : The content of water in hydrates were measured using a simultaneous thermal analyzer TA® SDT Q600. In this study, the samples were heated from room temperature to $1100{ }^{\circ} \mathrm{C}$ at a rate of $20^{\circ} \mathrm{C} \mathrm{min}^{-1}$ under dry $\mathrm{N}_{2}$ as purging gas at $100 \mathrm{~mL} \mathrm{~min}^{-}$ ${ }^{1}$. Before testing, selected small samples, broken by the testing machine, were picked up and then stored in hermetically closed bottles under ethanol. At 91 days, these stored samples remained inside a desiccator during 5 days. After that, the dried samples were ground by using pestle and mortar up to the grain size as small as $45 \mu \mathrm{m}$. Finally, after weighting 6-10 mg of ground sample, the weighted samples were poured into a $90 \mu$ $\mathrm{L}$ alumina crucible. The procedure to quantify the normalized water in hydrates is found elsewhere [22].

4) Bulk density of cement pastes: The procedure for determining the density of blended cement pastes was according to ASTM C20.

\section{RESULTS AND DISCUSSIONS}

A. Hydration process of blended cement pastes after curing for 91 days

Using conjointly QXRD with TGA-DSC, the mineralogical composition of blended cement pastes at a W/B ratio of 0.3 after curing for 91 days, given in Tables III and IV, showed similar hydration products for both curing conditions, although different in amounts. The main hydration products observed in blended cement pastes were C-S-H, CH, $\mathrm{C}_{4} \mathrm{AH}_{13}$, as well as Cc. On the other hand, the content of Qz, previously observed in primary characterization of SCM, remained almost constant up to 91 days [17], [18], This suggests that it may act as filler during the whole experiment, but instead the content of zeolites decreased under the alkaline environment of cement hydration. Only $\mathrm{Cc}$ in Limo may also act as filler during the hydration of Limo blends because Limo beforehand contained Cc [17], [18].

The hydration process was not completed at such a low W/B ratio regardless of curing conditions. $\mathrm{C}_{3} \mathrm{~S}$ and $\mathrm{C}_{2} \mathrm{~S}$ were significantly observed in all blended cement pastes at ages as late as 91 days, even when the blended cement pastes were cured under water. As reported before, the water curing condition can scarcely complete the hydration of cement phases $[5],[6]$.

The amount of C-S-H, estimated by the amorphous content in QXRD [23], presented higher values as proportioning increased regardless of curing conditions. Rather than explaining this effect as an increase in the content of $\mathrm{C}-\mathrm{S}-\mathrm{H}$ caused by the pozzolanic reaction, it is possible that such increases can be due to the amorphous content of SCM. In fact, the pozzolanic reaction scarcely proceeds at low W/B regardless of the curing condition [18].

$14^{\text {th }}$ LACCEI International Multi-Conference for Engineering, Education, and Technology: "Engineering Innovations for 
For comparison of both curing conditions, cluster analyses of the X-ray diffractograms were used to group the plain and blended cement pastes according to their mineralogy. These cluster analyses were done based on their peak positions, and the Principal component plots of the clusters are shown in Figures 1 and 2 for water and air curing conditions, respectively. Comparing both curing conditions, the results for air-cured samples were more widely scattered than those under water curing condition. These differences in mineralogy were observed because the air curing condition negatively affected the reaction of SCM, hydration of cement phases, and increased the amount of carbonates.

Under water curing condition, the clusters of zeoliteblended cement pastes are, in turn, situated close to those of the control because their mineralogical compositions show a high similarity. It is possible that at higher hydration process like water curing condition, the zeolitic crystalline structure likely collapsed, then it could not be detected by QXRD. Consequently, zeolite blended cement pastes presented similar mineralogical phases to plain cement pastes, but Limo blended cement pastes did not.

Normalized water in hydrates, being an overall indicator of the content of hydrates, were generally higher in blended cement pastes than in plain ones. As shown in Figure 4, the higher the dosage, the higher the amount of hydrates regardless the curing condition. Additionally in this Figure showed that the content of hydrates are higher under water curing condition that in air one. Indeed in air curing condition, the evolution of the normalized water in hydrates was almost stopped by drying conditions[17]. Among blended cement paste, Zeo2 blends showed higher amounts of hydrates than the others under water curing condition. It is possible that since Zeo2 is less dense due to its high porosity, it can act as an internal reservoir providing extra water for hydration. This effect has been reported in zeolite aggregates [24]. Despite of grain size, it is possible that water in zeolitic pores can be released when its crystalline structure collapsed during hydration. In air curing condition, all SCM blended cement pastes showed almost the same content of hydrates, even at a high volume of replacement suggesting that the hydration was almost stopped. Under water curing condition, in contrast these hydrates can be still forming at an age of 91 days.

The curing condition affects the incorporation of water in hydrates. It has been reported that in full hydrated plain cement pastes can incorporate $0.23 \mathrm{~g}$ of water per $\mathrm{g}$ of cement [25]. Under these curing conditions, although the water in hydrates increased with the dosage, all of the blended cement pastes showed lower values of normalized water than that of full hydrated cement pastes.

The consumption of $\mathrm{CH}$ by the pozzolanic reaction leads to show less amount of $\mathrm{CH}$ in blended cement pastes than that in plain ones. This would be referred as a proof that the pozzolanic reaction proceeds. In this study, the content of $\mathrm{CH}$ normalized with respect to the content of cement was on average higher in plain cement pastes than in blended one regardless of the curing condition as can be shown in Figure 5. This suggests that the pozzolanic reaction scarcely proceeded at a $W / B$ ratio of 0.3 .

Although, the amount of $\mathrm{CH}$ was higher under water curing condition than in air one, the carbonation is expected to be higher in air curing condition than under water one [3]. In air curing condition, $\mathrm{CH}$ can be diminished by the pozzolanic reaction at early ages [26]-[28]; the carbonation can be the most influencing reaction in the long term [29], [30]. Regarding to Cc observed in water-cured specimens, it is likely due to sample handling

Under both curing conditions, the density decreased as the dosage increased due to dilution effect as can be seen on Figure 6. Comparing the density for both curing conditions, the density was higher in air curing condition than under water one. One possible reason for higher density in air curing condition may be related to an increase in the amount of carbonates. Regarding to this, $\mathrm{Cc}$, being heavier than other hydration products and easily observed in air-cured specimens, could form within pore system of cementitious matrix, thus leading to an increase in the density with time [31].

We can also notice that there were several levels of reactivity in these SCMs in part because of their mineralogical composition. This suggests that Zeo2 could consume a higher amount of $\mathrm{CH}$ in part due to the presence of HEU-CLI and reactive silica, that easily reacted at early ages, but instead MOR, mostly observed in Zeo1, is more stable than other zeolites [32]. It would seem that the difference in pozzolanic activity mainly depends not only on curing condition but also on mineralogical composition and the content of reactive silica.

In summary, as a consequence of the factors considered in this study, the effect of poor curing conditions on hydration parameters can be regarded as a decrease in the content of hydrates and content of $\mathrm{CH}$; an increase in the density and carbonates. 


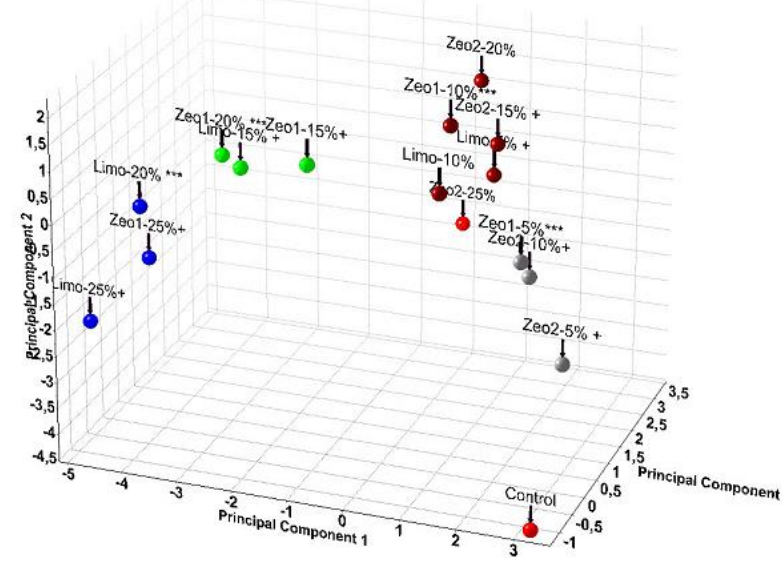

FIG. 1 PRINCIPAL COMPONET ANALYSIS SCORE PLOT OF BLENDED CEMENT PASTES UNDER WATER CURING CONDITIONS

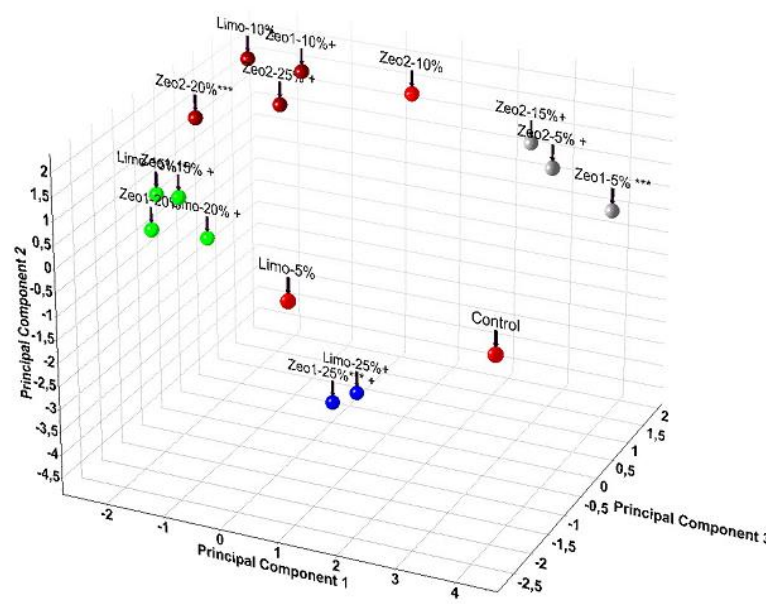

FIG. 2 PRINCIPAL COMPONET ANALYSIS SCORE PLOT OF BLENDED CEMENT PASTES IN AIR CURING CONDITIONS

TABLE III

QUANTITATIVE MINERALOGY FOR PLAIN AND BLENDED CEMENT PASTES CURED UNDER WATER AFTER 91 DAYS (IN WT. \%)

\begin{tabular}{|l|l|l|l|l|l|l|l|l|}
\hline SCM & $\begin{array}{l}\text { Pr } \\
\text { op }\end{array}$ & C3S & C2S & CH & Cc & Qz & Zeo & $\begin{array}{l}\text { CSH } \\
*\end{array}$ \\
\hline Control & 0 & 6.6 & 1.8 & 14.1 & & & & 77.9 \\
\hline \multirow{5}{*}{ Zeo1 } & 5 & 4.0 & 2.8 & 11.6 & & 0.6 & & 80.9 \\
\cline { 2 - 9 } & 10 & 5.2 & 1.5 & 11.4 & & 1.6 & & 80.8 \\
\cline { 2 - 9 } & 15 & 4.7 & & 12.0 & & 2.8 & & 80.3 \\
\cline { 2 - 9 } & 20 & 3.7 & 0.4 & 9.1 & 2.3 & 3.1 & & 83.4 \\
\cline { 2 - 9 } & 25 & 4.0 & 1.4 & 9.1 & 3.9 & 4.2 & & 80.6 \\
\hline \multirow{2}{*}{ Zeo2 } & 5 & 5.2 & 2.0 & 10.5 & 5.1 & 0.3 & & 80.8 \\
\cline { 2 - 9 } & 10 & 4.2 & 1.0 & 8.8 & 1.8 & 0.5 & & 84.8 \\
\hline
\end{tabular}

\begin{tabular}{|l|l|l|l|l|l|l|l|l|}
\hline \multirow{5}{*}{} & 15 & 4.7 & 0.9 & 8.7 & 2.2 & 0.7 & & 84.5 \\
\cline { 2 - 9 } & 20 & 4.2 & 0.9 & 8.5 & 2.8 & 1.3 & & 83.8 \\
\cline { 2 - 9 } & 25 & 5.5 & 0.8 & 9.2 & 1.6 & 2.6 & 4.2 & 77.3 \\
\hline \multirow{4}{*}{ Limo } & 5 & 6.6 & 4.0 & 12.0 & 1.7 & 1.0 & & 74.3 \\
\cline { 2 - 9 } & 10 & 4.5 & 1.9 & 9.7 & 4.8 & 2.1 & & 78.3 \\
\cline { 2 - 8 } & 15 & 4.0 & 0.4 & 9.9 & 1.5 & 3.3 & & 80.8 \\
\cline { 2 - 8 } & 20 & 2.8 & & 8.9 & 2.4 & 4.0 & & 81.5 \\
\cline { 2 - 8 } & 25 & 3.4 & 1.8 & 11.1 & 4.0 & 6.5 & & 72.7 \\
\hline
\end{tabular}

* Amorphous content in QXRD

TABLE IV

QUANTITATIVE MINERALOGY FOR PLAIN AND BLENDED CEMENT PASTES CURED IN AIR AFTER 91 DAYS (IN WT. \%)

\begin{tabular}{|l|l|l|l|l|l|l|l|l|}
\hline SCM & Proport. & $\mathrm{C} 3 \mathrm{~S}$ & $\mathrm{C} 2 \mathrm{~S}$ & $\mathrm{CH}$ & $\mathrm{Cc}$ & $\mathrm{Qz}$ & Zeo & CSH$^{*}$ \\
\hline Control & 0 & 13.7 & 7.2 & 13.1 & 0.4 & & & 65.6 \\
\hline Zeo1 & 5 & 9.5 & 6.6 & 7.5 & & 0.7 & & 69.9 \\
\cline { 2 - 9 } & 10 & 10.4 & 6.6 & 12.1 & & 1.7 & & 68.5 \\
\hline & 15 & 5.1 & & 8.6 & & 1.9 & & 80.4 \\
\cline { 2 - 9 } & 20 & 6.6 & 1.5 & 8.8 & 3.2 & 3.4 & & 76.9 \\
\cline { 2 - 9 } & 25 & 6.3 & 3.1 & 7.6 & 5.6 & 4.5 & & 72.1 \\
\hline Zeo2 & 5 & 10.4 & 5.5 & 9.3 & 3.6 & 0.4 & & 72.0 \\
\cline { 2 - 9 } & 10 & 8.9 & 4.6 & 9.3 & 3.4 & 0.6 & & 74.2 \\
\cline { 2 - 9 } & 15 & 10.2 & 2.5 & 7.3 & 6.6 & 1.1 & 1 & 71.9 \\
\cline { 2 - 9 } & 20 & 6.7 & 2.6 & 9.3 & 1.7 & 2.2 & 3.2 & 76.9 \\
\cline { 2 - 9 } & 25 & 7.0 & 2.3 & 7.8 & 1.7 & 2.9 & 4.5 & 75.9 \\
\hline \multirow{5}{*}{ Limo } & 5 & 5.8 & 3.4 & 9.5 & 1.0 & 0.8 & & 79.8 \\
\cline { 2 - 9 } & 10 & 7.3 & 3.8 & 10.8 & 1.1 & 2.6 & & 74.8 \\
\cline { 2 - 8 } & 15 & 6.7 & 0.4 & 9.8 & 1.5 & 3.5 & & 78.2 \\
\cline { 2 - 8 } & 20 & 5.2 & & 9.3 & 3.1 & 5.0 & & 73.8 \\
\cline { 2 - 8 } & 25 & 5.3 & 3.1 & 6.9 & 7.0 & 5.9 & & 71.8 \\
\hline
\end{tabular}

* Amorphous content in QXRD

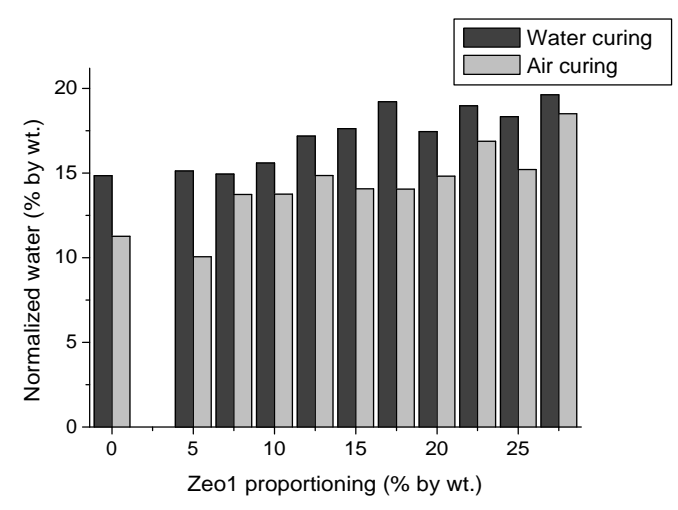

14 ${ }^{\text {th }}$ LACCEI International Multi-Conference for Engineering, Education, and Technology: "Engineering Innovations for Global Sustainability”, 20-22 July 2016, San José, Costa Rica. 

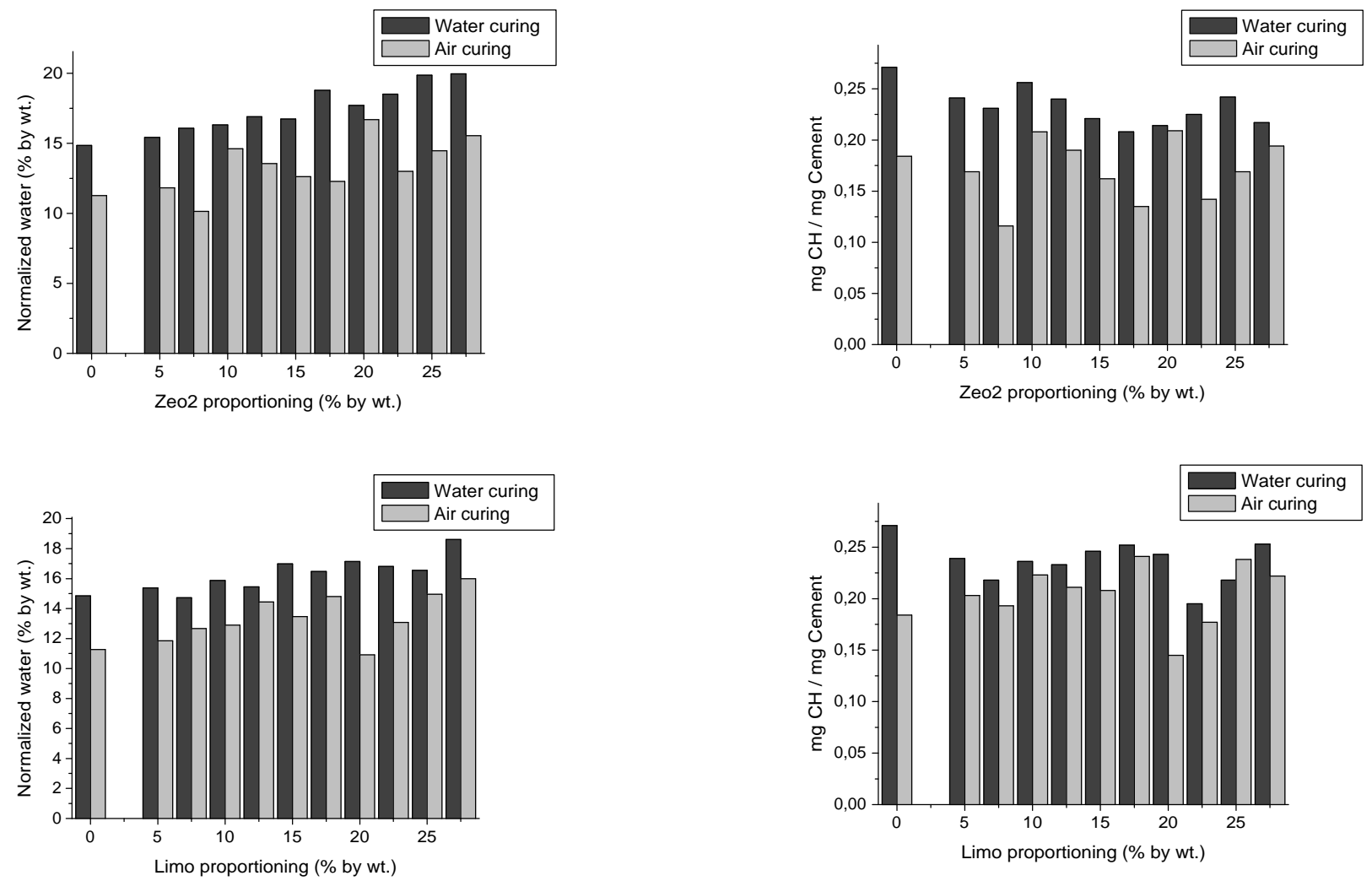

FIG 4: EVOLUTION OF PERCENTAGE OF THE NORMALIZED WATER IN HYDRATES AS FUNCTION OF TIME ON THE TOP, AND OF PROPORTIONING ON THE BOTTOM

FIGURE 5 EVOLUTION OF THE RATIO OF MG CH PER MG CEMENT AS FUNCTION OF TIME ON THE TOP, AND OF PROPORTIONING ON THE BOTTOM
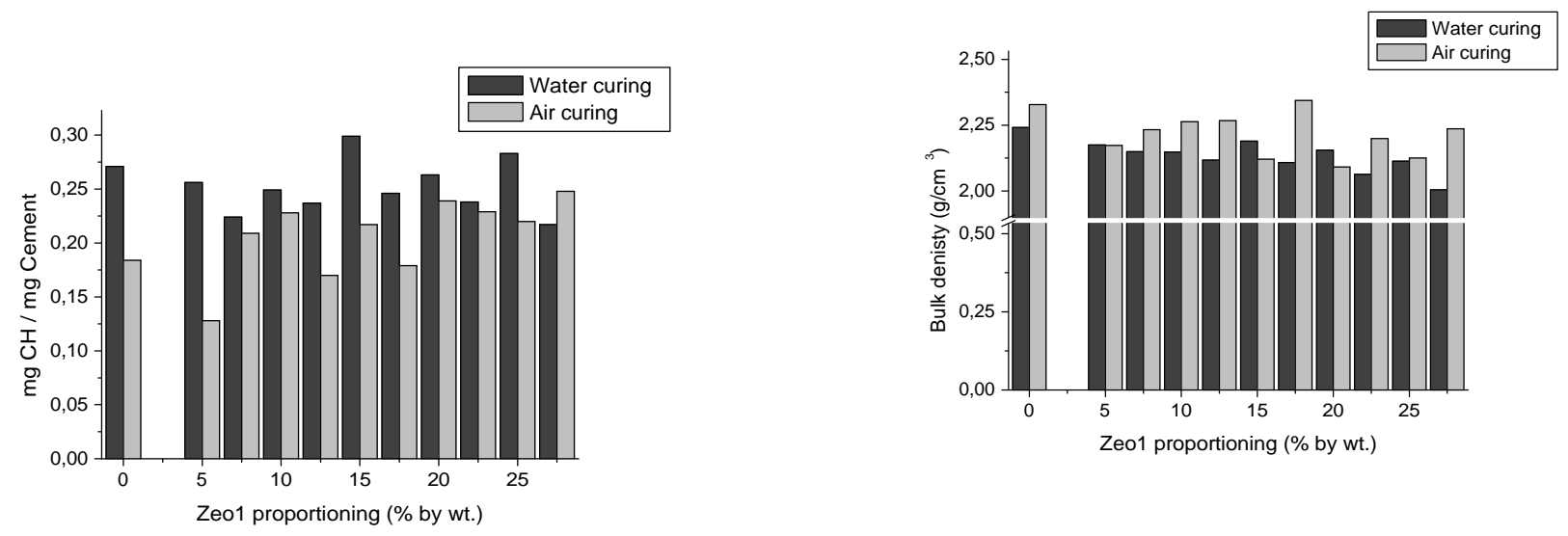

$14^{\text {th }}$ LACCEI International Multi-Conference for Engineering, Education, and Technology: "Engineering Innovations for Global Sustainability", 20-22 July 2016, San José, Costa Rica. 

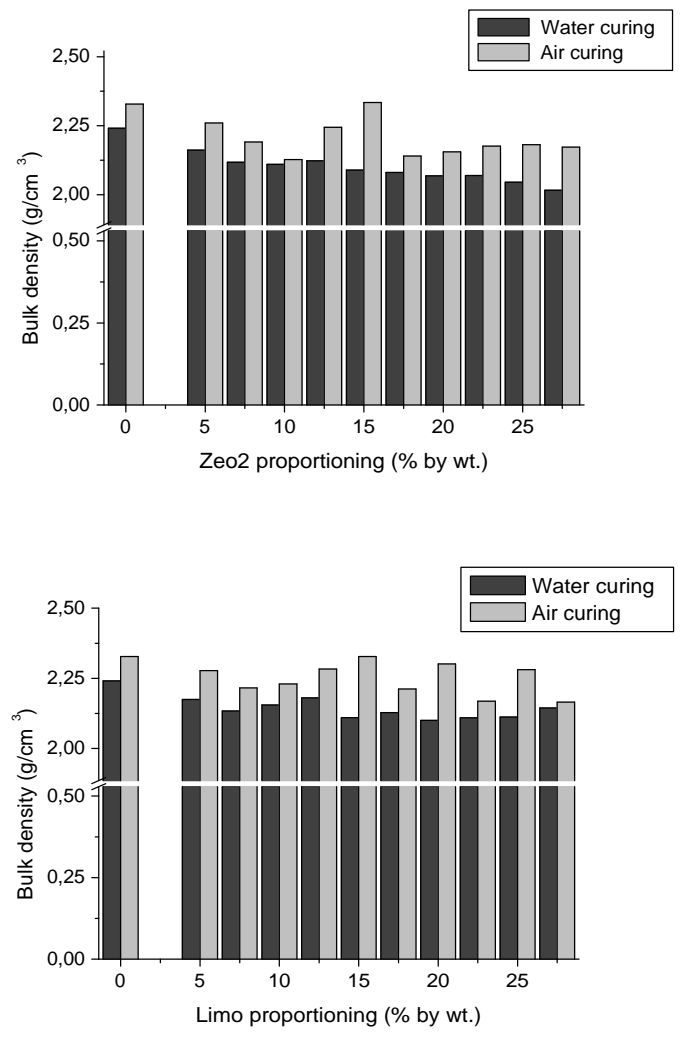

FIGURE 6 EVOLUTION OF THE BULK DENSITY AS FUNCTION OF TIME ON THE TOP, AND OF PROPORTIONING ON THE BOTTOM

\section{B. Compressive strength}

In Figure 7, a comparison in terms of compressive strength as function of dosage can be seen for both water and air curing conditions. There is a meaningful difference between both curing. The water-cured blended cement pastes were about twice higher than air-cured ones. The compressive strength was the most affected parameter by the availability of water for curing. It seems that the pozzolanic reaction is diminished by a low W/B ratio and consequently exerted a less effect on mechanical performance in air curing condition, although the pozzolanic reaction was more important on water-cured specimens.

We can notice that the compressive strength was meaninglessly affected by the dosage as evidenced by no overall trend over the proportioning regardless of curing condition.

In case of Zeo1 (MOR)-blended cement pastes, these showed the highest compressive strength under water curing condition. This result is in accord with Fragoulis et al and Poon. [9], [7]. But instead in air curing condition their performances were the worst.
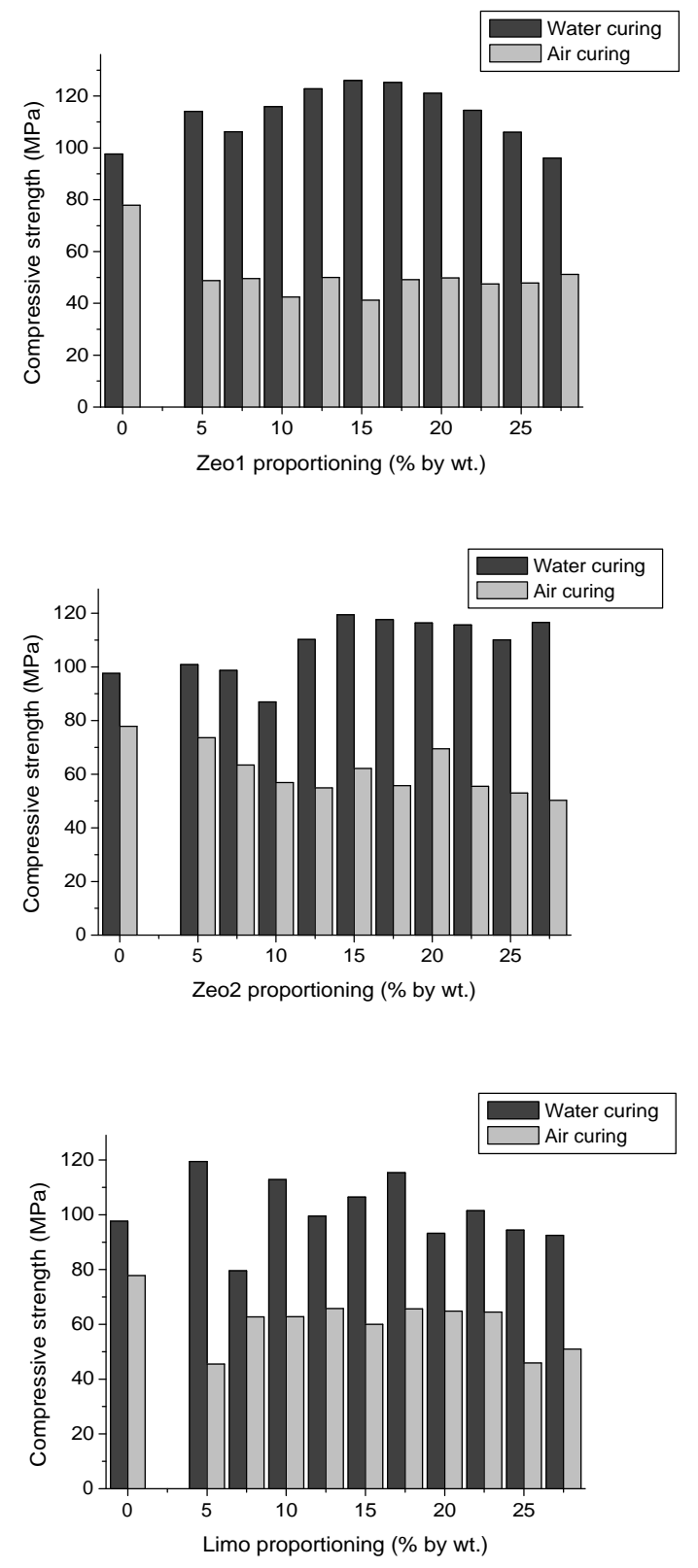

FIGURE 7 EVOLUTION OF THE COMPRESSIVE STRENGTH AS FUNCTION OF TIME ON THE TOP, AND OF PROPORTIONING ON THE BOTTOM

On the other hand, Zeo2 and Limo blended cement pastes show lower compressive strengths than Zeo1-blends under water curing condition. In air curing condition, these SCMblended cement pastes were in turn higher than Zeo1-blended cement pastes.

In accordance with the results of compressive strength, the best type of SCM, which achieved the highest value, was mordenite rich tuffs; but it was the most sensitive to curing condition as well. Since this tuffs is closer to Guayaquil than 
heulandite-clinoptilolite, it can be the best option for using as SCM in the local cement industry.

\section{CONCLUSION}

As consequence of the factors considered in this and the preceding studies, the curing condition affected the hydration process in many ways. Air curing condition can decrease the content of hydrates, and mainly $\mathrm{CH}$, but an increase in the density and carbonation. These hydration parameters shift as the availability of water for curing increases.

The zeolite tuffs were able to collapse more rapid under water curing condition than in air one. This leads to the watercured blended cement pastes presented a similar mineralogical composition. In turn, more heterogeneous composition is observed in air cured ones.

Blended cement pastes at a W/B ratio of 0.3 showed less water incorporated in hydrates than that of full hydrated cement pastes regardless of curing condition.

It is possible that the pozzolanic reaction scarcely proceeded in air curing condition at such a low W/B ratio. Under this condition, the carbonation may play a crucial role in consuming the $\mathrm{CH}$ formed by the hydration.

The increase in the density observed in air-cured specimens compared to water-cured ones is likely due to a higher carbonation in air curing condition.

The most important effect of water curing condition on blended cement pastes is a meaningful increase in the compressive strength achieving twice higher values compared to those cured in air. MOR-blended cement pastes showed the highest compressive strength under water curing condition, however these pastes were the worst affected by air curing condition.

\section{ACKNOWLEDGMENT}

The author would like to acknowledge the financial support of RIP2010 project, as well as the facilities of LEMAT and CIDNA-ESPOL.

\section{REFERENCES}

[1] H. J. H. Brouwers, "The work of Power and Brownyard revisited: Part 2," Cem. Concr. Res., vol. 35, pp. 19221936, 2005.

[2] H. J. H. Brouwers, "The work of Power and Brownyard revisited: Part I,” Cem. Concr. Res., vol. 34, pp. 16971716, 2004.

[3] K. Meeks and N. Carino, "Curing of high-performance concrete: Report of the state-of-the-art," NIST: National Institute of Standard and Technology. United states department of commerce technology administration, NISTIR 6295, 1999.

[4] R. De Gennaro and A. Langella, "Use of zeolite- rich rocks and waste materials for the production of structural lightweight concretes," Appl. Clay Sci., vol. 41, pp. 6172, 2008.
[5] C. Colella, M. De Gennaro, and R. Aiello, "Use of Zeolitic Tuff in the Building Industry," in Reviews in Mineralogy and Geochemistry, D. Bish and D. W. Ming, Eds. 2001, pp. 551-587.

[6] N.-Q. Feng and G.-F. Peng, "Applications of natural zeolite to construction and building materials in china.," Constr. Build. Mater., vol. 19, pp. 579-584, 2005.

[7] C. S. Poon, L. Lam, and S. C. Kou, "A study on the hydration rate of natural zeolite blended cement pastes," Constr. Build. Mater., vol. 13, pp. 427-432, 1999.

[8] K. Luke, "The effect of natural zeolite on the composition of cement pore fluids at early ages," in 12 th international congress in cement chemistry, 2007, p. - .

[9] D. Fragoulis, E. Chaniotakis, and M. Stamatakis, "Zeolitic tuffs of kimolos island, aegean sea, greece and their industrial potential," Cem. Concr. Res., vol. 27, pp. 889-905, 1997.

[10] K. L. Scrivener and A. Nonat, "hydration of cementitious materials, present and future," Cem. Concr. Res., vol. 41, pp. 651-665, 2011.

[11] M. Valipour, P. Farhad, M. Shekarchi, and S. Khani, "Comparing a natural pozzolan, zeolite, to metakaolin and silica fume in terms of their effect on the durability characteristics of concrete: A laboratory study.," Constr. Build. Mater., vol. 41, pp. 879-888, 2013.

[12] R. E. Rodriguez-Camacho and R. Uribe-Afif, "Importance of using the natural pozzolana on concrete durability," Cem. Concr. Res., vol. 32, pp. 1851-1858, 2002.

[13] B. Ahmadi and M. Shekarchi, "Use of natural zeolite as a supplementary cementitious material," Cem. Concr. Compos., vol. 32, pp. 134-141, 2010.

[14] A. A. Ramezanianpour, "Effect of curing on the compressive strength, resistance to chloride ion penetration and porosity of concrete incorporating slag, fly ash or silica fume," Cem. Concr. Compos., vol. 17, pp. 125-133, 1995.

[15] J. Hill and J. Sharp, "The mineralogy and microstructure of three composite cements with high replacement levels.," Cem. Concr. Compos., vol. 24, pp. 191-199, 2002.

[16] F. Massazza, "Pozzolana and Pozzolanic Cement," in Lea's Chemistry of Cement and Concrete, vol. 4th, P. C. Hewlett, Ed. Oxford, 1998, pp. 471-636.

[17] M. H. Cornejo, J. Elsen, C. Paredes, and H. Baykara, "Hydration and strength evolution of air-cured zeoliterich tuffs and siltstone blended cement pastes at low water-to-binder ratio," Clay Miner., vol. 50, no. 1, pp. 133-152, Mar. 2015.

[18] M. H. Cornejo, J. Elsen, H. Baykara, and C. Paredes, "Hydration process of zeolite-rich tuffs and siltstoneblended cement pastes at low W/B ratio, under wet curing condition," Eur. J. Environ. Civ. Eng., vol. 18, no. 6, pp. 629-651, Jul. 2014. 
[19] R. Snellings and L. Machiels, "Rietveld refinement stratergy for quantitative phase analysis of partially amorphous zeolitized tuffaceous rocks," Geol. Belg., vol. 13/3, pp. 183-196, 2011.

[20] L. Kaufman and P. Rousseeuw, Finding groups in Data: an introduction to Cluster Analysis. New York: Wiley, 1990.

[21] L. A. Kelley, S. P. Gardner, and M. J. Sutcliffe, “An automated approach for clustering an ensemble of NMRderived protein structures into conformationally-related subfamilies," Protein Eng., vol. 9, pp. 1063-1065, 1996.

[22] M. Cornejo, J. Elsen, C. Paredes, and H. Baykara, "Thermomechanical treatment of two Ecuadorian zeoliterich tuffs and their potential usage as supplementary cementitious materials," J Therm Anal Calorim, vol. 115, pp. 309-321, 2013.

[23] T. Matsushita and S. Hoshino, "Effect of curing temperature and water to cement ratio hydration of cement compounds," in 12 th international congress in cement chemistry, 2007, p. - .

[24] S. Ghourchian, M. Wyrzykowski, P. Lura, M. Shekarchi, and B. Ahmadi, "An investigation on the use of zeolite aggregates for internal curing of concrete," Constr. Build. Mater., vol. 40, pp. 135-144, 2013.

[25] K. C. Hover, "The influence of water on the performance of concrete," Constr. Build. Mater., no. 25, pp. 30033013, 2011.

[26] R. Snellings, G. Mertens, and J. Elsen, "Supplementary Cementitious Materials," vol. 74, M. Broekmans and H. Pöllmann, Eds. Review in Mineralogy and Geochemistry, 2012, pp. 211-278.

[27] R. Snellings, G. Mertens, Ö. Cizer, and J. Elsen, "Early age hydration and pozzolanic reaction in natural zeolite blended cements: Reaction kinetics and products by in situ synchrotron X ray powder diffraction.," Cem Concr Res, vol. 40, pp. 1704-1713, 2010.

[28] D. Caputo, B. Liguori, and C. Colella, "Some advance in understanding the pozzolanic activity of zeolites: The effect of zeolite structure," Cem. Concr. Compos., vol. 30, pp. 455-462, 2007.

[29] P. H. R. Borges, J. O. Costa, N. Milestone, and C. Lynsdale, "Carbonation of $\mathrm{CH}$ and $\mathrm{CSH}$ in composite cement pastes containing high amounts of BFS," Cem. Concr. Res., vol. 40, pp. 284-292, 2010.

[30] V. Papadakis and M. Fardis, "Hydration and carbonation of pozzolanic cements," ACI Mater. J., vol. 89, pp. 119130, 1992.

[31] M. Balonis and F. P. Glasser, "The density of cement phases," Cem. Concr. Res., vol. 39, pp. 733-739, 2009.

[32] D. Bish and J. W. Carey, "Thermal Behavior of Natural Zeolites," in Reviews in Mineralogy and Geochemistry, D. Bish and D. W. Ming, Eds. 2001, pp. 403-452.

$14^{\text {th }}$ LACCEI International Multi-Conference for Engineering, Education, and Technology: "Engineering Innovations for 